\title{
ANALISIS FAKTOR YANG MEMENGARUHI OSTEOPOROSIS PADA IBU MENOPAUSE DI PUSKESMAS STABAT KABUPATEN LANGKAT
}

\author{
Ira Syafira ${ }^{1}$, Razia Begum Suroyo ${ }^{2}$, Tri Niswati Utami ${ }^{3}$ \\ ${ }^{1,2}$ Fakultas Kesehatan Masyarakat Institut Kesehatan Helvetia Medan \\ ${ }^{3}$ Fakultas Kesehatan Masyarakat Universitas Islam Negeri Sumatera Utara \\ Email : irasyafira1919@gmail.com ${ }^{1}$, razia.begum@helvetia.ac.id ${ }^{2}$, \\ triniswatiutami@uinsu.ac.id ${ }^{3}$
}

\begin{abstract}
Osteoporosis is a condition or disease in which bones become fragile and easily cracked or broken. Based on medical record data obtained in 2015, 106 cases of osteoporosis were found in menopausal and elderly women. This study aims to determine and analyze the effects of age, physical activity, smoking, family history, history of fractures on osteoporosis in menopausal mothers. The method used was the mix methods research method with a sequential Explanatory research model with a quantitative sample of 87 respondents and informants on a qualitative approach that was 10 menopausal women and health workers. Data collection techniques using questionnaires and research interview instruments. Data analysis was a multivariate analysis using the binary logistic test. The results indicated that there was an effect between age from the results of statistical tests of $.044<.05$, physical activity of $.012<.05$, family history of $.014<.05$ and history of fracture of $.035<.05$, the smoking variable of $.223>.05$. The most dominant variable has an influence that was the family history variable with an OR value of 36.869. The conclusion shows that there is an influence between the age of physical activity, family history and history of fractures on osteoporosis in menopausal women but the smoking variable has no effect on osteoporosis in menopausal mothers. It is hoped that this research can be an input for health centers in managing osteoporosis and can improve the management of osteoporosis prevention programs with health promotion efforts.
\end{abstract}

Keywords: osteoporosis, age, physical activity, smoking, family history, fracture history

\section{PENDAHULUAN}

Osteoporosis merupakan kondisi atau penyakit dimana tulang menjadi rapuh dan mudah retak atau patah. Osteoporosis adalah suatu penyakit yang ditandai dengan berkurangnya massa tulang dan adanya perubahan mikroarsitektur (bentuk mikro) jaringan tulang yang mengakibatkan menurunnya kekuatan tulang dan meningkatnya kerapuhan tulang, sehingga menyebabkan tulang mudah patah. Osteoporosis dijuluki sebagai silent epidemic diseases, karena menyerang secara diam, tanpa adanya tanda khusus, sampai pasien mengalami patah tulang (Misnadiarly, 2013).

Osteoporosis kini telah menjadi salah satu penyebab penderitaan dan cacat yang paling sering terjadi pada 
orang berusia lanjut, terutama pada wanita. Ketika wanita mencapai usia menopause, maka semakin menurun pula kadar kalsium dalam tulang. Sebelum terjadi fase menopause, biasanya didahului dengan fase premenopause. Premenopause adalah masa 4-5 tahun sebelum menopause. Bagi kebanyakan perempuan gejala fase premenopause mulai muncul pada usia 40 tahun yang menimbulkan gejala yang sangat mengganggu aktivitas kehidupan wanita, termasuk hilangnya kesuburan dan meningkatnya risiko osteoporosis pada kondisi menjelang menopause (Proverawati, 2010).

World Health Organization (WHO) menentukan kriteria tentang tingkat keparahan keropos tulang yang sudah diterima oleh seluruh dunia. Bila T-score $<-2,5$ digolongkan sebagai osteoporosis. Nilai $T$-score di bawah -1,0 dinamakan osteopenia atau massa tulang yang rendah. Nilai $T$-score di antara -1 sampai +1 tergolong BMD (Bone Mineral Density) normal. Osteoporosis terjadi jika laju penghancuran tulang meningkat, sedangkan pembentukan kembali menurun, sehingga tulang menjadi rapuh dan keropos (World Health Organization, 2004).
Wanita memiliki risiko osteoporosis lebih tinggi dibanding lakilaki, hal ini dikarenakan wanita mengalami proses kehamilan dan menyusui serta penurunan hormon estrogen pada saat premenopause, menopause dan pasca menopause. Pada pria juga memiliki risiko terkena osteoporosis, penyakit osteoporosis pada pria juga dipengaruhi oleh hormon. Bedanya laki-laki tidak mengalami menopause, sehingga osteoporosis datang lebih lambat (La Ode, 2012).

Penyebab osteoporosis diantaranya, yaitu rendahnya hormon estrogen pada wanita, rendahnya aktivitas fisik, kurangnya paparan sinar matahari, kekurangan vitamin $\mathrm{D}$, usia lanjut dan rendahnya asupan kalsium. Hal ini terbukti dengan rendahnya konsumsi kalsium rata-rata masyarakat Indonesia yaitu sebesar $254 \mathrm{mg}$ per hari, hanya seperempat dari standar internasional, yaitu 1000-1200 mg per hari untuk orang dewasa (Tandra, 2009).

Seiring bertambahnya usia, daya serap kalsium akan menurun. Diperkirakan selama hidup, wanita akan kehilangan massa tulang 30\%-50\%, sedangkan pria 20\%-30\%. Selain itu, diperkirakan $80 \%$ kepadatan tulang 
diwariskan secara genetik sehingga osteoporosis dapat diturunkan. Setiap tahun sekitar 25 juta wanita di seluruh dunia diperkirakan mengalami menopause. Jumlah wanita usia 50 tahun ke atas diperkirakan meningkat dari 500 juta pada saat ini menjadi lebih dari 1 miliar pada 2030, sedangkan wanita premenopause sebanyak 342 juta. Di Asia, masih menurut data World Health Organization (WHO), pada 2025 jumlah wanita yang berusia tua diperkirakan akan melonjak dari 107 juta ke 373 juta (Briot et al., 2018).

Penderita osteoporosis di Eropa, Jepang, dan Amerika adalah sebanyak 75 juta penduduk, sedangkan di Cina 84 juta penduduk, dan ada 200 juta penderita osteoporosis diseluruh dunia. Penderita osteoporosis di Inggris, satu dari tiga wanita dan satu dari dua belas pria diatas 50 tahun akan mengalami pengeroposan tulang (osteoporosis). Penderita osteoprosis di Australia bertambah dari $15 \%$ pada wanita usia 60-64 tahun menjadi $71 \%$ pada usia 80 tahun, dan bagi pria dengan usia yang sama, angka meningkat dari 1,6\% menjadi 19\% (Briot et al., 2018).

Hasil penelitian yang dilaksanakan bersama perhimpunan Osteoporosis Indonesia, melaporkan bahwa proporsi penderita Osteoporosis pada penduduk yang berusia diatas 50 tahun, adalah $32,3 \%$ pada wanita dan $28,8 \%$ pada pria. Menurut hasil analisa data yang dilakukan oleh Puslitbang Gizi Depkes pada 14 provinsi menunjukkan bahwa masalah osteoporosis di Indonesia telah mencapai tingkat yang perlu di waspadai yaitu 19,7\%. Itulah sebabnya kecenderungan osteoporosis di Indonesia 6 kali lebih tinggi dibandingkan dengan Negeri Belanda. Lima provinsi dengan risiko osteoporosis tertinggi adalah Sumatera Selatan (27,7\%), Jawa Tengah (24,02\%), di Yogyakarta (23,5\%), Sumatera Utara (2,82\%), Jawa Timur $(21,42 \%)$ dan Kalimantan Timur (10,5\%) (Kemenkes RI, 2015).

Berdasarkan analisis data dan risiko osteporosis yang dilakukan Departemen Kesehatan RI pada tahun 2006. Fonterra Brands Indonesia, pravalensi osteoporosis di Indonesia saat ini telah mencapai 41,75\%. Artinya setiap 2 dari 5 penduduk Indonesia memiiki risiko terkena osteoporosis. Hal ini lebih tinggi dari pravalensi dunia yang hanya 1 dari 3 berisiko osteoprosis (Depkes RI, 2009).

Wanita yang mendekati menopause, produksi hormon estrogen, 
hormon progesteron dan hormon seks lainnya mulai menurun (Kusmiran, 2011). Perubahan yang terjadi pada usia menopause antara lain: perubahan organ repoduksi, perubahan hormon, perubahan fisik dan perubahan emosi. Akibat perubahan organ reproduksi maupun hormon tubuh pada saat menopause akan mempengaruhi berbagai keadaan fisik tubuh seorang wanita yang berupa keluhan ketidaknyamanan yaitu hot fluses (perasaan panas), keringat berlebih, vagina kering, tidak dapat menahan air seni, hilangnya jaringan penunjang, penambahan berat badan, gangguan mata, nyeri tulang dan sendi (Manuaba, 2009).

Menopause merupakan sebuah kata yang memiliki banyak arti atau makna yang terdiri dari kata men dan pauseis yang berasal dari bahasa Yunani, yang digunakan untuk menjelaskan gambaran berhentinya haid atau menstruasi yang terjadi pada usia 49-51 tahun. Hal ini merupakan akhir proses biologis dari siklus menstruasi, yang dikarenakan terjadinya perubahan hormon yaitu penurunan produksi hormon estrogen yang dihasilkan ovarium (Northrup, 2006).
Menopause ada hubungannya dengan menarche (haid yang pertama kali datang) semakin dini menarche terjadi, makin lambat menopause terjadi. Pada saat ini, semakin dini datangnya menarche akan mengakibatkan semakin lambat datangnya menopause, sehingga membuat masa reproduksi menjadi lebih panjang (Kahn et al., 2002).

$$
\text { Kecenderungan }
$$

populasi perempuan menopause di Indonesia semakin tinggi. Menurut data Departemen Kesehatan (Depkes) perempuan Indonesia yang memasuki menopause sebesar $7,4 \%$ dari populasi pada tahun 2000. Jumlah tersebut diperkirakan meningkat menjadi $11 \%$ pada tahun 2005 dan akan naik lagi sebesar $14 \%$ atau sekitar 30 juta orang pada tahun 2015. Peningkatan populasi perempuan menopause pada umumnya akan disertai berbagai tingkat dan jenis permasalahan yang kompleks yang berdampak pada peningkatan masalah kesehatan perempuan menopause tersebut (Depkes RI, 2009).

Wanita di kota besar seperti Medan rata-rata mengalami menopause di akhir usia 40-an tahun atau di awal 50 tahun, namun kini menurut penelitian terbaru, 1 dari 16 wanita berisiko menopause dini. Seperti profil penduduk yang tergambar 
di salah satu Kelurahan Sei Sikambing Medan, pada tahun 2011 jumlah penduduk perempuan jauh lebih banyak dari laki-laki. Disana juga didapatkan jumlah usia lansia yang cukup banyak. Ada sekitar 76 jiwa perempuan sudah mengalami menopause (Safitri, 2009).

Berdasarkan data rekam medik yang diperoleh dari Wilayah Kerja Puskesmas Stabat Kabupaten Langkat, pada tahun 2015 sebanyak 106 kasus osteoporosis ditemukan pada wanita menopause dan lanjut usia. Jumlah kasus osteoporosis meningkat setiap tahunnya terutama pada wanita lanjut usia yang telah mengalami menopause. Mengingat besarnya pravalensi dan risiko terjadinya osteoporosis terutama pada wanita lanjut usia yang mengalami menopause, menarik perhatian peneliti untuk melakukan penelitian dengan judul "Analisis Faktor Risiko yang Memengaruhi Terjadinya Osteoporosis Pada Ibu Menopause di Desa Pantai Gemi Wilayah Kerja Puskesmas Stabat Kabupaten Langkat Tahun 2019”.

\section{METODE PENELITIAN}

Penelitian yang menggunakan pendekatan mix methods dengan jenis penelitian kuantitatif desain cross sectional dan kualitatif desain studi kasus. Creswell menyebutkan mix methods merupakan pendekatan penelitian yang mengkombinasikan atau menggabungkan bentuk kuantitatif dan kualitatif. Mix Methods juga merupakan metode penelitian yang memberikan asumsi bahwa dalam menunjukan arah atau memberi petunjuk tentang cara pengumpulan dan menganalisis data, serta perpaduan pendekatan kuantitatif dan kualitatif melalui beberapa fase proses penelitian.

Penelitian ini dilakukan di Desa Pantai Gemi Wilayah Kerja Puskesmas Stabat Kabupaten Langkat dan penelitian ini dilakukan pada bulan Oktober 2019. Populasi dalam penelitian ini adalah seluruh ibu yang telah memasuki usia menopause. Data yang digunakan dalam penelitian ini adalah data sekunder. Populasi penelitian ini sebanyak $87 \mathrm{ibu}$ yang dirawat yang telah memasuki usia menopause dan sampel dalam penelitian ini diambil menggunakan teknik total populasi yaitu 87 orang.

Analisis data yang digunakan yaitu analisis multivariat. Analisis Multivariat bertujuan untuk melihat kemaknaan korelasi antara variabel bebas (independent variable) dengan variabel terikat (dependent variable) di lokasi penelitian secara simultan dan sekaligus 
menentukan faktor-faktor yang lebih dominan berpengaruh. Uji statistik yang digunakan untuk analisis multivariat yaitu Regression Binary Logistic (Regresi Binari Logistik) pada batas kemaknaan $95 \%$ dengan perhitungan statistik $\alpha=0,05$.

HASIL

Oleh karena penelitian ini menggunakan dua pendekatan, maka hasil disajikan sesuai pendekatan yang digunakan

\section{Penelitian Kuantitatif}

Tabel 1 Hasil Uji Regresi Binari Logistik

\begin{tabular}{|c|c|c|c|c|}
\hline & Variabel & B & Sig. & $\operatorname{Exp}(B)$ \\
\hline \multirow{6}{*}{$\begin{array}{l}\text { Step } \\
1^{\mathrm{a}}\end{array}$} & Usia & 2,852 & 0,046 & 17,314 \\
\hline & $\begin{array}{l}\text { Aktifitas } \\
\text { Fisik }\end{array}$ & 4,984 & 0,027 & 146,106 \\
\hline & Merokok & 2,742 & 0,223 & 0,064 \\
\hline & $\begin{array}{l}\text { Riwayat } \\
\text { Keluarga }\end{array}$ & 3,565 & 0,018 & 35,329 \\
\hline & $\begin{array}{l}\text { Riwayat } \\
\text { Fraktur }\end{array}$ & 3,791 & 0,019 & 44,310 \\
\hline & Constant & $\begin{array}{c}- \\
7,400\end{array}$ & 0,001 & 0,001 \\
\hline \multirow{5}{*}{$\begin{array}{l}\text { Step } \\
2^{\mathrm{a}}\end{array}$} & Usia & 2,661 & 0,044 & 14,317 \\
\hline & $\begin{array}{l}\text { Aktifitas } \\
\text { Fisik }\end{array}$ & 3,442 & 0,012 & 31,259 \\
\hline & $\begin{array}{l}\text { Riwayat } \\
\text { Keluarga }\end{array}$ & 3,607 & 0,014 & 36,869 \\
\hline & $\begin{array}{l}\text { Riwayat } \\
\text { Fraktur }\end{array}$ & 3,085 & 0,035 & 21,859 \\
\hline & Constant & $\begin{array}{c}- \\
7,822\end{array}$ & 0,001 & 0,000 \\
\hline
\end{tabular}

Berdasarkan tabel 1. di atas pada penelitian ini menggunakan $\alpha=0,05$, variabel bebas (independen) yang mempunyai pengaruh secara signifikan dengan variabel terikat (dependen) adalah usia memiliki nilai sig-p $0,044<$ 0,05 artinya usia memiliki pengaruh secara signifikan terhadap kejadian osteoporosis. Aktifitas fisik memiliki nilai sig-p $0,012<0,05$ artinya aktifitas fisik memiliki pengaruh secara signifikan terhadap kejadian osteoporosis. Riwayat keluarga memiliki nilai sig-p $0,014<0,05$ artinya riwayat keluarga memiliki pengaruh secara signifikan terhadap kejadian osteoporosis. Riwayat fraktur memiliki nilai sig- $p 0,035<0,05$ artinya riwayat fraktur memiliki pengaruh secara signifikan terhadap kejadian osteoporosis di Wilayah Kerja Puskesmas Stabat tahun 2019.

\section{Penelitian Kualitatif}

Hasil wawancara yang dilakukan pada informan yaitu ibu yang mengalami osteoporosis di Wilayah Kerja Puskesmas Stabat, di dapat hasil wawancara bahwasannya terkait faktor resiko terjadinya osteoporosis, dari 10 informan seluruh informan mengatakan terkena osteoporosis, namun berdasarkan tingkat lamanya informan terkena osteoporosis berbeda-beda, dan asumsi dari informan terkait faktor penyebab terjadinya osteoporosis dominan informan mengatakan 
dikarenakan usia informan yang sudah memasuki usia tua dan 1 dari 10 informan mengatakan pernah mengalami jatuh dan patah tulang namun memungkinkan bukan menjadi faktor penyebab informan tersebut mengalami osteoporosis. 2 dari 10 informan yang diwawancarai mengatakan memiliki riwayat osteoporosis pada keluarganya, dan dari 10 informan tidak ada informan yang merokok.

\section{PEMBAHASAN}

Hasil penelitian menunjukkan bahwa variabel usia memiliki nilai sig-p $0,044<0,05$ artinya usia memiliki pengaruh secara signifikan terhadap kejadian osteoporosis di Wilayah Kerja Puskesmas Stabat tahun 2019. Hasil OR pada variabel usia menunjukkan nilai OR 14,317 maka usia $\geq 50$ tahun memiliki pengaruh terhadap kejadian osteoporosis sebanyak 14 kali lipat dibandingkan usia $<50$ tahun. Oleh karena nilai $\mathrm{B}=$ Logaritma Natural dari $14,317=2,661$. Oleh karena nilai $\mathrm{B}$ bernilai positif, usia mempunyai pengaruh positif terhadap kejadian osteoporosis.

Penelitian ini tidak sejalan dengan penelitian Kridianan yang bertujudul "Faktor Risiko Osteoporosis Pada Wanita Pascamenopause Di RSUD
Kota Tangerang, yang mana hasil penelitian menunjukkan bahwa, terdapat hubungan yang signifikan antara usia dengan osteoporosis pada wanita pascamenopause di RSUD Kota Semarang. Usia memiliki hubungan dengan kejadian osteoporosis yang dilihat dari hasil analisia diperoleh $\mathrm{p}=$ 0,023 berdasarkan pengambilan keputusan uji chi square untuk uji hipotesis dimana nilai $\mathrm{p}<0,05$. Karena nilau $\mathrm{p}=0,023<0,05$ maka dapat dikatakan bahwa terdapat hubungan yang bermakna antara faktor risiko usia dengan terjadinya osteoporosis pada wanita pascamenopause di RSUD Kota Semarang (Kridiana, 2012).

Berdasarkan hasil penelitian menunjukkan bahwa usia memiliki pengaruh terjadinya osteoporosis. Hal ini dikarenakan dengan kebiasaan hidup sehat pada usia berapapun maka terjadinya osteoporosis dapat dihindari. Namun begitu ibu yang berusia > 50 tahun tidak menutup kemungkinan akan mengalami osteoporosis, dimana semakin tinggi usia ibu, proporsi osteoporosis juga semakin besar. Secara teori juga disebutkan bahwa setelah usia 30 tahun, masa tulang yang hilang akan lebih banyak dari pada masa tulang yang dibentuk, sehingga dengan 
meningkatnya usia, masa tulang akan semakin berkurang. Teori menyebutkan bahwa periode menopause berpengaruh terhadap masa tulang karena adanya penurunan jumlah hormon estrogen dan progesteron. Penurunan estrogen sebagai pelindung massa tulang, berpengaruh terhadap massa tulang akan lebih cepat berkurang. Terjadinya menopause yang lebih awal akan mengakibatkan penurunan masa tulang yang lebih awal pula.

Hasil penelitian menunjukkan bahwa variabel aktifitas fisik memiliki nilai sig- $p 0,012<0,05$ artinya aktifitas fisik memiliki pengaruh secara signifikan terhadap kejadian osteoporosis di Wilayah Kerja Puskesmas Stabat tahun 2019. Hasil OR pada variabel usia menunjukkan nilai OR 31,259, maka aktifitas fisik yang tidak baik memiliki pengaruh terhadap kejadian osteoporosis sebanyak 31 kali lipat dibandingkan aktifitas fisik yang baik. Nilai $\mathrm{B}=$ Logaritma Natural dari $31,259=3,442$. Oleh karena nilai $\mathrm{B}$ bernilai positif, aktifitas fisik mempunyai pengaruh positif terhadap kejadian osteoporosis.

Selanjutnya penelitian yang dilakukan oleh Renidayati tahun 2011 tentang Faktor Risiko terjadinya
Osteoporosis pada Wanita Menopause, menunjukkan bahwa $33,3 \%$ responden mengalami osteoporosis, $33,3 \%$ responden memiliki badan kurus, 51\% responden memiliki aktifitas rendah dari $54,9 \%$ responden memiliki diet buruk. Terdapat hubungan yang bermakna antara ukuran tubuh, aktifitas (latihan) dan diet dengan kejadian osteoporosis $(\mathrm{p}=0,000)$. Disarankan kepada pimpinan Puskesmas Bangkiang untuk mengeluarkan kebijakan rutin untuk wanita tentang pentingnya aktifitas (latihan) dan meningkatkawn diet bagi wanita menopause (Renidayati, Clara, \& Sunardi, 2011).

Berdasarkan hasil penelitian aktifitas fisik sangat mempengaruhi pembentukan masa tulang, beberapa hasil penelitian menunjukkan aktifitas fisik seperti berjalan kaki, berenang dan naik sepeda pada dasarnya memberi pengaruh melindungi tulang dan menurunkan demineralisasi tulang karena pertambahan umur. Kurang aktifitas karena istirahat di tempat tidur yang berkepanjangan dan mengurangi masa tulang. Hidup dengan aktifitas fisik yang cukup dapat menghasilkan massa tulang yang lebih besar. Proporsi osteoporosis seseorang yang memiliki tinggi aktifitas fisik dan beban pekerjaan 
harian tinggi saat berusia 25 sampai 55 tahun cenderung sedikit lebih rendah daripada yang memiliki aktifitas fisik tingkat sedang dan rendah.

Hasil peneltian menunjukkan bahwa variabel merokok memiliki nilai sig-p 0,223 >0,05 artinya aktifitas fisik memiliki pengaruh secara signifikan terhadap kejadian osteoporosis di Wilayah Kerja Puskesmas Stabat tahun 2019. Hasil OR pada variabel merokok menunjukkan nilai OR 0,064, maka merokok memiliki pengaruh terhadap kejadian osteoporosis sebanyak 0,1 kali lipat dibandingkan yang tidak merokok. Nilai $\mathrm{B}=$ Logaritma Natural dari 0,064= $-2,742$. Oleh karena nilai $\mathrm{B}$ bernilai negatif, maka merokok mempunyai pengaruh negatif terhadap kejadian osteoporosis.

Penelitian yang dilakukan oleh Dimyati tahun 2017 tentang Pengaruh Antara Aktivitas Fisik, Kebiasaan Merokok dan Sikap Lansia terhadap Kejadian Osteoporosis, menunjukkan bahwa ada pengaruh $(\mathrm{p}<0,05)$ antara aktivitas fisik, kebiasaan merokok, dan sikap terhadap kejadian osteoporosis. Odds Ratio (OR) yang diketahui dalam penelitian ini, yaitu pada aktivitas fisik sebesar 14,764, kebiasaan merokok sebesar 9,646, dan sikap sebesar 5,623.
Kesimpulan dalam penelitian ini adalah aktivitas fisik yang paling berpengaruh terhadap kejadian osteoporosis setelah dikontrol kebiasaan merokok dan sikap lansia (Dimyati, 2017).

Berdasarkan hasil penelitian kerusakan tulang akibat rokok merupakan proses jangka panjang, sehingga semakin muda usia seseorang pertama kali merokok maka semakin besar mengalami osteoporosis di masa tua. Saat usia anak-anak hingga usia 30 tahun merupakan masa dimana tubuh menyimpan nutrisi untuk membangun kepadatan tulang. Ketika individu merokok pada masa tersebut maka kemampuan tubuh untuk menyimpan nutrisi akan berkurang sehingga mereka yang merokok akan memiliki masa tulang yang lebih rendah saat dewasa. Kepadatan kandungan mineral pada tulang individu perokok dilaporkan lebih rendah 15-30\% dibandingkan orang-orang yang tidak merokok. Setelah usia 30 tahun maka massa tulang akan menurun dengan sendirinya secara perlahan, dan proses regenerasinya pun ikut melambat. Pada masa ini, kepadatan tulang yang hilang tidak akan bisa kembali. Dengan ditambah kebiasaan merokok, maka proses penurunan kepadatan tulang bisa terjadi 
bahkan lebih cepat lagi sehinga berkembang menjadi osteopenia, yang merupakan gejala awal osteoporosis.

Variabel riwayat keluarga memiliki nilai sig- $p$ 0,014 $<0,05$ artinya riwayat keluarga memiliki pengaruh secara signifikan terhadap kejadian osteoporosis di Wilayah Kerja Puskesmas Stabat tahun 2019. Hasil OR pada variabel riwayat keluarga menunjukkan nilai OR 36,869, maka responden yang terdapat riwayat keluarga osteoporosis memiliki pengaruh terhadap kejadian osteoporosis sebanyak 37 kali lipat dibandingkan yang tidak memiliki riwayat keluarga osteoporosis. Oleh karena nilai $\mathrm{B}=$ Logaritma Natural dari 36,869 = 3,607. Oleh karena nilai B bernilai positif, riwayat keluarga mempunyai pengaruh positif terhadap kejadian osteoporosis.

Penelitian yang dilakukan oleh Ramadani tahun 2010 tentang FaktorFaktor Risiko Osteoporosis dan Upaya Pencegahannya, menunjukkan bahwa faktor-faktor risiko terjadinya osteoporosis adalah faktor yang bisa dirubah (alkohol, merokok, BMI kurang, kurang gizi, kurang olahraga, jatuh berulang) dan faktor yang tidak bisa diubah (umur, jenis kelamin, riwayat keluarga, menopause, penggunaan kortikosteroid, rematoid arthritis). Karena puncak kepadatan tulang dicapai pada sekitar usia 25 tahun, maka sangatlah penting untuk membangun tulang yang kuat di sepanjang usia, sehingga tulang-tulang akan tetap kuat dikemudian hari. Asupan kalsium yang memadai merupakan bagian penting untuk membangun tulang yang kuat (Ramadani, 2010).

Berdasarkan hasil penelitian faktor genetika juga memiliki konstribusi terhadapa massa tulang. Anak perempuan dari wanita yang mengalami patah tulang osteoporosis rata-rata memiliki masa tulang yang lebih rendah daripada anak seusia mereka (kira-kira 3-7\% lebih rendah). Riwayat adanya osteoporosis dalam keluarga sangat bermanfaat dalam menentukan faktor risiko seseorang mengalami patah tulang, sama halnya pada penelitian ini yang mana menunjukan faktor riwayat keluarga berpengaruh terhadap terhadap kejadian osteoporosis di Puskesmas Stabat Kabupaten Langkat yang mana dapat dilihat dari hasil uji statistik diperoleh nilai probabilitas sebesar 0,038 $<0,05$.

Hasil penelitian menunjukkan variabel riwayat fraktur memiliki nilai sig- $p 0,035<0,05$ artinya riwayat fraktur 
memiliki pengaruh secara signifikan terhadap kejadian osteoporosis di Wilayah Kerja Puskesmas Stabat tahun 2019. Hasil OR pada variabel merokok menunjukkan nilai OR 21,859, maka yang ada riwayat fraktur memiliki pengaruh terhadap kejadian osteoporosis sebanyak 22 kali lipat dibandingkan yang tidak memiliki riwayat fraktur. Oleh karena nilai $\mathrm{B}=$ Logaritma Natural dari $21,859=3,085$. Oleh karena nilai B bernilai positif, riwayat fraktur mempunyai pengaruh positif terhadap kejadian osteoporosis.

Penelitian yang dilakukan oleh Santoso tahun 2012 tentang FaktorFaktor Penyebab Osteoporosis, menunjukkan bahwa terdapat faktorfaktor yang dapat menyebabkan osteoporosis, baik osteoporosis primer maupun osteoporosis sekunder dengan patofisiologinya, dimana dari semua faktor penyebab yang ada ditemukan adanya penurunan densitas masa tulang yang nyata disertai dengan peningkatan risiko terjadinya fraktur pada tulang tersebut (Santoso, 2012).

Berdasarkan hasil penelitian pada orang yang pernah patah tulang panggul akan berisiko mengalami patah tulang belakang 2-3 kali dan patah tulang panggul 1-2 kali.
Beberapa penelitian sebelumnya telah menyebutkan bahwa, riwayat fraktur merupakan salah satu faktor risiko osteoporosis, namun berbanding terbalik dengan penelitian ini, yang mana pada penelitian ini menunjukan faktor riwayat fraktur tidak ada pengaruh terhadap terhadap kejadian osteoporosis di Puskesmas Stabat Kabupaten Langkat yang mana dapat dilihat dari hasil uji statistik diperoleh nilai probabilitas sebesar 0,035 $<0,05$. Fraktur atau patah tulang adalah keadaan dimana hubungan atau kesatuan jaringan tulang terputus. Tulang mempunyai daya lentur (elastisitas) dengan kekuatan yang memadai, apabila trauma melebihi dari daya lentur tersebut maka terjadi fraktur (patah tulang). Osteoporosis adalah penyakit tulang sistemik dan fraktur osteoporosis dapat terjadi pada tiap tempat. Meskipun fraktur yang berhubungan dengan kelainan ini meliputi thorak dan tulang belakang (lumbal), radius distal dan femur proksimal.

Hasil penelitian juga menunjukkan bahwa variabel yang paling besar memiliki pengaruhnya terhadap kejadian osteoporosis yaitu variabel riwayat keluarga, dimana responden yang terdpat riwayat keluarga osteoporosis, memiliki 
pengaruh terhadap kejadian osteoporosis sebanyak 37 kali lipat dibandingkan yang tidak ada memiliki riwayat keluarga osteoporosis.

\section{KESIMPULAN}

Kesimpulan pada penelitian ini yaitu ada pengaruh antara usia, aktivitas fisik, riwayat keluarga dan riwayat fraktur terhadap osteoporosis pada ibu menopause namun pada variabel merokok tidak terdapat pengaruh terhadap osteoporosis pada ibu menopause di Wilayah Kerja Puskesmas Stabat Kabupaten Langkat.

\section{SARAN}

Hasil penelitian ini diharapkan dapat menjadi masukan bagi puskesmas dalam penanganan osteoporosis dan dapat meningkatkan pengelolaan program pencegahan osteoporosis dengan upaya-upaya promosi kesehatan yang berkaitan dengan variabel-variabel penelitian ini dengan tujuan memberi informasi kepada ibu yang mulai memasuki usia menopause tentang pentingnya menjaga kesehatan dan mencegah dari osteoporosis, karena wanita menopause pada usia diatas 50 tahun lebih berisiko untuk terkena osteoporosis.

\section{DAFTAR PUSTAKA}

Briot, K., Roux, C., Thomas, T., Blain, H., Buchon, D., Chapurlat, R., ...
Cortet, B. (2018). 2018 update of French Recommendations on the Management of Postmenopausal Osteoporosis. Joint Bone Spine, $85(5)$, 519-530. https://doi.org/10.1016/j.jbspin.201 8.02.009

Depkes RI. (2009). Kecenderungan Osteoporosis di Indonesia 6 Kali Lebih Tinggi Dibanding Negeri Belanda. Jakarta: Departemen Kesehatan Republik Indonesia.

Dimyati, K. F. (2017). Pengaruh Antara Aktivitas Fisik, Kebiasaan Merokok dan Sikap Lansia terhadap Kejadian Osteoporosis. Jurnal Berkala Epidemologi, 5(1), 107-117. https://doi.org/10.20473/jbe.v5i1

Kahn, E. B., Ramsey, L. T., Brownson, R. C., Heath, G. W., Howze, E. H., Powell, K. E., ... Corso, P. (2002). The Effectiveness of Interventions to Increase Physical Activity A Systematic Review and the Task Force on Community Preventive Services. Am J Prev Med, 22(4S), 73-108.

https://doi.org/10.1016/S07493797(02)00434-8

Kemenkes RI. (2015). InfodatinOsteoporosis. Jakarta: Kementerian Kesehatan Republik Indonesia Pusat Data dan Informasi.

Kridiana, O. (2012). Faktor Risiko Osteoporosis Pada Wanita Pascamenopause (Studi di Rumah Sakit Umum Daerah Kota Semarang). Fakultas Ilmu Keolahragaan Universitas Negeri Semarang, 1-93.

Kusmiran. (2011). Kesehatan Reproduksi Remaja dan Wanita. 
Jakarta: Salemba Medika.

La Ode, S. (2012). Asuhan Keperawatan Genetik. Yogyakarta: Nuha Medika.

Manuaba, I. A. C. (2009). Memahami Kesehatan Reproduksi Wanita. Jakarta: Arcan.

Misnadiarly. (2013). Osteoporosis Pengenalan, Faktor Risiko, Pencegahan dan Pengobatan. Jakarta: Permata Puri Media.

Muhammad, I. (2015). Panduan penyusunan Karya Tulis Ilmiah Bidang Kesehatan Menggunakan Metode Ilmiah. Bandung: Cita Pustaka Media Perintis.

Northrup. (2006). Bijak Disaat Menopause Menciptakan Kesehatan Fisik dan Emosional Saat Menghadapi Perubahan. Bandung: Q-Press.

Proverawati, A. (2010). Menopause dan Sindrom Pramenopause.

Yogyakarta: Nuha Medika.

Ramadani, M. (2010). Faktor-Faktor Resiko Osteoporosis dan Upaya Pencegahannya. Studi Literatur, 4(2), 111-115.

Renidayati, Clara, \& Sunardi. (2011). Faktor Risiko Terjadinya Osteoporosis Pada Wanita Menopause. NERS Jurnal Keperawatan, $\quad 7(2), \quad 130$. https://doi.org/10.25077/njk.7.2.13 $0-135.2011$

Safitri, A. (2009). Beberapa Faktor Yang Mempengaruhi Menopause Pada Wanita Di Kelurahan Titi Papan Kota Medan Tahun 2009. Fakultas Kesehatan Masyarakat Universitas Sumatera Utara.

Santoso, P. B. (2012). Faktor-Faktor Penyebab Osteoporosis. Skripsi.
Tandra, H. (2009). Osteoporosis. Jakarta: Gramendia Pustaka Utama. World Health Organization. (2004). Who Scientific Group on the Assessment of Osteoporosis At Primary Health. 5-7. 